\title{
Personal spend on cigarettes and tobaccos in Cuba from 2013 to
}

\section{6}

\author{
Efraín Sánchez González ${ }^{1}$ and Fé Fernández Hernández ${ }^{*}$ \\ ${ }^{1}$ Faculty of Medical Sciences " 10 de Octubre". \\ ${ }^{2}$ Faculty of Medical Sciences "10 de Octubre"
}

* Corresponding author: Fé Fernández Hernández, Faculty of Medical Sciences "10 de Octubre".

Received date: July 02, 2020; Accepted date: July 23, 2020; published date: July 27, 2020

Citation: Fé F Hernández, Efraín S González, (2020) Clinical Reviews and Clinical Trials. 2(2); DOI: 10.31579/2693-4779/011

Copyright: (C) 2020 Fé Fernández Hernández, This is an open-access article distributed under the terms of the Creative Commons Attribution License, which permits unrestricted use, distribution, and reproduction in any medium, provided the original author and source are credited.

\begin{abstract}
Introduction: As risk factor smoking means a social opportunity cost because of the whole goods and services didn't obtained to satisfice the tobacco and cigarettes demand. While the tobacco and cigarettes spend is increasing these opportunity cost will be increasing too.
\end{abstract}

Objective: To describe the tobacco and cigarettes spends in Cuba since 2013 to 2016.

Materials and methods: Was made a descriptive and longitudinal research about the tobacco and cigarettes spends in Cuba from 2013 to 2016. Were utilized two rates: monthly per capita sales on cigarettes and tobaccos measured in pesos and monthly per capita sales on cigarettes and tobaccos respect to middle salary measured in percent. Theoric methods: Historic - Logic, Inductive - Deductive, Comparative and Analysis and Synthesis. Empiric methods: documental and bibliographic research and arithmetic calculus. All the statistic processing was in Microsoft Excel 2007.

Results: The personal spend on cigarettes and tobaccos from 2013 to 2016 shows a stable and defined structure.

Conclusions: Havana, Santiago de Cuba provinces and the Special Municipality Isla de la Juventud were the Cuban regions showed consumption rate higher than the national middle.

Key words: smoking, consumption, structure.

\section{Introduction.}

Smoking means a high social opportunity cost because of all goods and services didn't obtained. This cost increase with the tobacco intensity consumption growing's and the smoker number. The increasing of this cost makes emphasis in the people poorness. That's why it is important to research the structure of the tobacco consumption and take measures to reduce the smoking consequences in the population. ${ }^{1-3}$

The developed countries are characterized by less personal spends in tobacco. This is because the higher tobacco consumption occurs in developing countries. Especially in higher producers like China. ${ }^{4}$

The accumulative character from smoking is given by the successive consumption of cigarettes and tobacco to satisfy the nicotine needs. The growing in tobacco consumption induced by before consumptions carries to reduce the available resources to afford the demand of needed goods. ${ }^{5}$

This situation is agreeing in Cuba too. This is the land of the called best tobacco around the world. Inside Cuba the social and cultural conditions had contributed to keep inside the tobacco consumption like social and cultural behavior. This condition had determined several epidemiologic consequences agreeing with the smoking impact. ${ }^{6-10}$

The description from the personal spends in tobacco and the impact over the personal economy constitutes a tool to measure the smoking social impact. Also, may be focused public policies agreeing with the regional impact too.

\section{Objective.}

To describe the tobacco and cigarettes spends in Cuba since 2013 to 2016.

\section{Materials and methods}

Was made a descriptive and longitudinal research about the tobacco and cigarettes spends in Cuba from 2013 to 2016. Were utilized two rates: monthly per capita sales on cigarettes and tobaccos measured in pesos and monthly per capita sales on cigarettes and tobaccos respect to middle salary measured in percent. The cited rates may be calculated like shows the following table. 


\begin{tabular}{|l|c|l|}
\hline \multicolumn{1}{|c|}{ Rate } & \multicolumn{1}{|c|}{ Formula } & \multicolumn{1}{c|}{ Interpretation } \\
\hline $\begin{array}{l}\text { Monthly per capita } \\
\text { sales on cigarettes and } \\
\text { tobaccos }\end{array}$ & $\begin{array}{c}\text { Annual tobacco and cigarettes sales } \\
\text { Population } * 12\end{array}$ & $\begin{array}{l}\text { Middle personal income } \\
\text { used to cover the } \\
\text { consumption of } \\
\text { cigarettes and tobaccos }\end{array}$ \\
\hline $\begin{array}{l}\text { Monthly per capita } \\
\text { sales on cigarettes and } \\
\text { tobaccos respect to } \\
\text { middle salary }\end{array}$ & Monthly per capita sales on cigarettes and tobaccos $* 100 \%$ & $\begin{array}{l}\text { Part from salary used to } \\
\text { cover the consumption } \\
\text { of cigarettes and } \\
\text { tobaccos. }\end{array}$ \\
\hline
\end{tabular}

As theoric methods were utilized the Historic - Logic, Inductive Deductive, Comparative and Analysis and Synthesis. As empiric methods were utilized the documental and bibliographic research and arithmetic calculus. All the statistic processing was in Microsoft Excel 2007.

Results.

Cuba is formed by 15 provinces and one especial municipality. The
Cubans provinces are Pinar del Río, Artemisa, La Habana, Mayabeque, Matanzas, Villa Clara, Cienfuegos, Sancti Spíritus, Ciego de Ávila, Camagüey, Las Tunas, Holguín, Granma, Santiago de Cuba and Guantánamo. The especial municipality is Isla de la Juventud. The application of the first rate suggested in all Cubans regions it show in the following table.

\begin{tabular}{|l|r|r|r|r|}
\hline Provinces & $\mathbf{2 0 1 3}$ & $\mathbf{2 0 1 4}$ & $\mathbf{2 0 1 5}$ & $\mathbf{2 0 1 6}$ \\
\hline Pinar del Río & 12,96 & 11,9 & 10,78 & 9,51 \\
\hline Artemisa & 8,76 & 11,67 & 13,03 & $\mathbf{1 5 , 7 7}$ \\
\hline La Habana & $\mathbf{1 9 , 1 7}$ & $\mathbf{2 2 , 7}$ & $\mathbf{2 3 , 6 3}$ & $\mathbf{1 9 , 5 9}$ \\
\hline Mayabeque & 14,98 & 13,36 & 13,58 & 12,49 \\
\hline Matanzas & $\mathbf{1 6 , 3 3}$ & $\mathbf{1 5 , 9}$ & $\mathbf{1 6 , 0 1}$ & 12,47 \\
\hline Villa Clara & $\mathbf{1 5 , 7}$ & 13,82 & 13,7 & 12,14 \\
\hline Cienfuegos & $\mathbf{1 6 , 2 4}$ & $\mathbf{1 5 , 6 1}$ & 9,46 & 8,48 \\
\hline Sancti Spíritus & 13,2 & 10,36 & 10,8 & 10,13 \\
\hline Ciego de Ávila & $\mathbf{1 6 , 8 2}$ & $\mathbf{1 6 , 6 5}$ & $\mathbf{1 6 , 7 2}$ & $\mathbf{1 4 , 8 7}$ \\
\hline Camagüey & 14,78 & 13,53 & 14,63 & 13,33 \\
\hline Las Tunas & 12,18 & 9,9 & 9,57 & 10,3 \\
\hline Holguín & 14,06 & 12,52 & 13,59 & 13,69 \\
\hline Granma & 13,57 & 11,88 & 11,44 & 11,36 \\
\hline Santiago de Cuba & $\mathbf{1 6 , 4 6}$ & $\mathbf{1 5 , 7 1}$ & $\mathbf{1 8 , 4 8}$ & $\mathbf{1 5 , 1 5}$ \\
\hline Guantánamo & 10,94 & 11,33 & 10,18 & 9,99 \\
\hline Isla de la Juventud & $\mathbf{1 7 , 8 9}$ & $\mathbf{1 7 , 8 7}$ & $\mathbf{1 7 , 5 2}$ & $\mathbf{1 5 , 8 7}$ \\
\hline CUBA & $\mathbf{1 5 , 2 1}$ & $\mathbf{1 5 , 0 7}$ & $\mathbf{1 5 , 3 8}$ & $\mathbf{1 3 , 7 9}$ \\
\hline
\end{tabular}

Table 1. Monthly per capita sales on cigarettes and tobaccos by Cuban region 2013 - 2016. Calculed by authors from the Cuban Yearbook.

From 2013 to 2016 the monthly per capita sales on cigarettes and tobaccos in whole Cuba was $\$ 14.86$. The regions that as middle more outcomes showed were Isla de la Juventud, Santiago de Cuba, Ciego de Ávila y La Habana. Pinar del Río, Mayabeque, Sancti Spíritus, Camagüey, Las
Tunas, Holguín, Granma and Guantánamo are the regions were the rate was always less than the national rate. ${ }^{11}$

These results should be interesting. However, an analysis in relative terms should be more interesting, as show the following table.

\begin{tabular}{|l|r|r|r|r|}
\hline Provinces & $\mathbf{2 0 1 3}$ & $\mathbf{2 0 1 4}$ & $\mathbf{2 0 1 5}$ & $\mathbf{2 0 1 6}$ \\
\hline Pinar del Río & $2,70 \%$ & $1,98 \%$ & $1,57 \%$ & $1,21 \%$ \\
\hline Artemisa & $1,95 \%$ & $2,12 \%$ & $1,95 \%$ & $\mathbf{2 , 0 3 \%}$ \\
\hline La Habana & $\mathbf{3 , 9 6 \%}$ & $\mathbf{3 , 8 2 \%}$ & $\mathbf{3 , 2 6 \%}$ & $\mathbf{2 , 5 2 \%}$ \\
\hline Mayabeque & $3,16 \%$ & $2,42 \%$ & $2,12 \%$ & $1,72 \%$ \\
\hline Matanzas & $3,37 \%$ & $\mathbf{2 , 6 2 \%}$ & $2,21 \%$ & $1,55 \%$ \\
\hline Villa Clara & $\mathbf{3 , 3 0 \%}$ & $2,29 \%$ & $1,95 \%$ & $1,50 \%$ \\
\hline Cienfuegos & $\mathbf{3 , 3 8 \%}$ & $\mathbf{2 , 5 6 \%}$ & $1,33 \%$ & $1,13 \%$ \\
\hline Sancti Spíritus & $2,71 \%$ & $1,69 \%$ & $1,54 \%$ & $1,28 \%$ \\
\hline
\end{tabular}




\begin{tabular}{|l|r|r|r|r|} 
Ciego de Ávila & $\mathbf{3 , 2 4} \%$ & $\mathbf{2 , 5 8 \%}$ & $2,22 \%$ & $1,82 \%$ \\
\hline Camagüey & $3,18 \%$ & $2,39 \%$ & $\mathbf{2 , 2 5 \%}$ & $\mathbf{1 , 9 6 \%}$ \\
\hline Las Tunas & $2,63 \%$ & $1,70 \%$ & $1,49 \%$ & $1,52 \%$ \\
\hline Holguín & $2,99 \%$ & $2,18 \%$ & $2,03 \%$ & $\mathbf{1 , 8 8 \%}$ \\
\hline Granma & $2,89 \%$ & $2,10 \%$ & $1,81 \%$ & $1,68 \%$ \\
\hline Santiago de Cuba & $\mathbf{3 , 7 2 \%}$ & $\mathbf{2 , 9 1 \%}$ & $\mathbf{2 , 9 4 \%}$ & $\mathbf{2 , 3 1 \%}$ \\
\hline Guantánamo & $2,47 \%$ & $2,07 \%$ & $1,63 \%$ & $1,58 \%$ \\
\hline Isla de la Juventud & $\mathbf{3 , 8 8 \%}$ & $\mathbf{3 , 3 7 \%}$ & $\mathbf{2 , 8 4 \%}$ & $\mathbf{2 , 4 2 \%}$ \\
\hline CUBA & $\mathbf{3 , 2 3 \%}$ & $\mathbf{2 , 5 8 \%}$ & $\mathbf{2 , 2 4 \%}$ & $\mathbf{1 , 8 6 \%}$ \\
\hline
\end{tabular}

Table 2. Monthly per capita sales on cigarettes and tobaccos respect to middle salary in Cuba 2013 - 2016. Calculed by authors from the Cuban Yearbook.

The part from salary used to cover the consumption of cigarettes and tobaccos showed a pointed tendency to decrease. In this period $\mathrm{La}$ Habana, Santiago de Cuba and Isla de la Juventud were the Cuban regions were the rate was always higher than the middle one.

The monthly per capita sales on cigarettes and tobaccos respect to the middle salary in Cuba showed a similar structure to the monthly per capita sales on cigarettes and tobaccos. In both case Isla de la Juventud, La Habana and Santiago de Cuba were the Cuban regions were the applied rate showed higher level than the national one.

This behavior is agreeing with smoking characteristic as addiction and risk factor. The region with more consumption will keep high consumption level because of the nicotine effect over the personal health. These regions should focus the priorities from the public policy to reduce the tobacco consumption. ${ }^{12}$

The suggested rates should be better because are base on the whole population and not on the smoker number. However, the not actualized information about smoking prevalence by region in the researched bibliography may not possible a better analysis.

The previous analysis may focus the strategic for the smoking control in the more affected Cuban regions. Understand why some Cuban region prefers pay more for tobacco and cigarettes than other one carries to an integral analysis where the economy play an important role. Nevertheless, it is important that all knowledge areas were closest agreeing with the smoking control. ${ }^{13}$

These results show the importance to continue following closest the smoking behavior since the economic and the epidemiologic point of view. By this way should be possible be more efficient applying public policies for the smoking control. ${ }^{14,15}$

\section{Conclusions}

The personal spends on tobaccos and cigarettes in Cuba in 2013 - 2016 showed a defined strucuture by Cuban regions. Was evidenced that Isla de la Juventud, La Habana and Santiago de Cuba were the Cuban regions were the personal spend on tobacco and cigarettes were higher.

\section{References}

1. Plá García Avelino, Elizarde Gálvez Miriam Gloria, Cárdenas Friera Evelio, Solares Carreño Juan Carlos, Nieves Sardiñas Blanca Nieves. (2016). Tabaquismo: valores e integralidad.

Rev.Med.Electrón. [Internet]. [citado 2018 Dic 13] ; 38( 3 ): 460-469.

2. Selvaraj S, Srivastava S, Karan A. (2015). Price elasticity of tobacco products among economic classes in India, 2011-2012. BMJ Open: e008180. doi: 10.1136/bmjopen-2015-008180.
3. León Román CA, Morgado Gutiérrez FC, Vázquez Borges B. (2017). Adicción al tabaco en estudiantes de enfermería técnica. Revista Cubana de Enfermería [revista en Internet]. [citado 2018 Dic 13];33(4):[aprox. 0 p.].

4. Jie Liu, Suhang Shang, Pei Li, Meiying Deng, Chen Chen, et al (2017). Asociación entre el tabaquismo actual y el deterioro cognitivo y su relación con la edad: estudio transversal realizado en Xi'an (China). MedicinaClínica, Volume 149, Issue 5, , Pages 203 208

5. Geri, Milvaet al. (2017). Eficiencia del Gasto Total en Salud: Análisis no paramétrico en una muestra amplia de países. Revista de Salud Pública [online]., v. 19, n. 1 [Accedido 3 Abril 2019] , pp. 79 85.

6. Sánchez E, Fernández F. La pérdida de productividad laboral atribuible al tabaquismo. Revista Cubana de Salud y Trabajo. 2016;17(2):57-60.

7. Sánchez E, Fernández F. Costo social por pérdida absoluta de productividad laboral. RevistaCubana de Salud y Trabajo 2018;19(1):33-9.

8. Fernández F, Sánchez E. (2016). Pérdida de productividad laboral por el consumo de cigarrillos en la jornada laboral. RevistaCubana de Salud y Trabajo;18(3):9-12.

9. Fernández Hernández F, Sánchez González E. (2017) Carga epidemiológica vs carga económica del tabaquismo por morbilidad. Rev. Ciencias Médicas de Pinar del Río. Marzo -abril,; vol. 21(2)210-216

10. Sánchez González E, Fernández Hernández F. (2017) El rol de las autoridades fiscales en el control del tabaquismo. Rev. Ciencias Médicas de Pinar del Río. Mayo-junio, vol 21(3)362-367..

11. ONEI. Anuario Estadístico de Cuba.

12. Fernández Hernández F, Sánchez González E. (2019). The socioeconomic inequity attributable to smoking. Journal of Medical Practice and Review [Internet] [citado 2019 Jun 15]; 3(6): 559 562.

13. Sánchez González E., Fernández Hernández F. (2018). La relación entre la política tributaria y el control del tabaquismo en Cuba. Correo científico Médico de Holguín. vol. (2)238-249.

14. Fernández Hernández F., Sánchez González E. (2019). Diploma Course: "The Social Smoking Cost in the National Economy", A Necessary andAppliable Tool. HSOA Journal ofCommunity Medicine and Public Health Care. Vol (6)052. Doi: 10.24966/CMPH-1978/100052.

15. Fernández Hernández F., Sánchez González E. (2019). Health Economic Evaluations for the Health Education Management. International Journal of Education Advancement. 1-4. Doi:IJEA100002 